\title{
Attitude and Behavior towards Self-medication using Non-steroidal Anti-inflammatory Drugs and Paracetamol among Housewives in Hegarmanah Village, Jatinangor
}

\author{
Kuswinarti, ${ }^{1}$ Aisyah Binti Mohamad Rohim, ${ }^{2}$ Siti Aminah ${ }^{3}$ \\ ${ }^{1}$ Department of Biomedical Sciences Faculty of Medicine Universitas Padjadjaran, Indonesia, \\ ${ }^{2}$ Faculty of Medicine Universitas Padjadjaran, Indonesia, ${ }^{3}$ Department of Neurology Faculty of \\ Medicine Universitas Padjadjaran/Dr. Hasan Sadikin General Hospital Bandung, Indonesia
}

\section{Abstract}

Background: The use of drugs by self-medication is widely practiced worldwide. One of the most common drugs used without prescription is analgesic and this is predominantly used among housewives since they are sometimes suffering from minor ailments due to house chores burden. The study aimed to explore the attitude and behavior of Non-steroidal Anti-inflammatory Drugs (NSAIDs) and paracetamol usage among housewives in Jatinangor, West Java-Indonesia.

Methods: A cross-sectional study was performed from August-November 2013. After informed consent, housewives living in Hegarmanah village, Jatinangor were included by filling in a validated questionnaire to assess the level of attitude and behavior of NSAIDs and paracetamol usage. The data were presented in percentages. The score was given and categorized as good, moderate and poor for both attitude and behavior.

Results: Of a total 110 housewives participated in this study, the attitude of housewife towards the drug use was good (59.1\%), moderate $(33.6 \%)$ and poor $(7.3 \%)$, whereas the behavior was good $(46.4 \%)$, moderate $(52.7 \%)$ and poor $(0.9 \%)$.

Conclusions: The majority of the respondents have moderate to good attitude as well as behavior toward the usage of NSAIDs and paracetamol as self-medication. Public health education and awareness are important to ensure safe and useful self-medication.

Keywords: Attitude, behavior, NSAIDs, paracetamol, self-medication

\section{Introduction}

The range of medicines available directly to the public is commonly practiced today with a wider choice and has been used as self-medication. ${ }^{1}$ Self-medication is determined as non-prescription drugs used by patients without consultation from medical practitioners. ${ }^{2,3}$ Based on the National Socio Economic Survey-Statistics Indonesia (Survey sosial ekonomi nasional-Badan Pusat Statistik, Susenas-BPS) Indonesia, in 2014, the percentage of population who have self-medication using modern medicine by $90.54 \%$, medicine traditional $20.99 \%$, and others $4.06 \% .{ }^{4}$ However, they do not practice self-medication correctly, whether the dosage is too high or wrong drug classes have been chosen which is not appropriate with the clinical symptoms. Self-medication can be beneficial for patients, healthcare providers, the pharmaceutical industry and governments, with a condition that the patients must have the responsibility of self-care. ${ }^{5}$

In Indonesia, drug classification is categorized into over-the-counter (OTC), limited OTC, controlled drugs and narcotics. ${ }^{7}$ Over-the-counter drugs are drugs that can be consumed without physician's prescription, ${ }^{7}$ for example for pain. Pain can be described as an unpleasant sensory and emotional experience associated with actual or potential

Correspondence: Kuswinarti, Department of Biomedical Sciences Faculty of Medicine Universitas Padjadjaran, Jalan Raya Bandung-Sumedang Km.21, Jatinangor, Sumedang, Indonesia, E-mail: wiwinsumarlan@yahoo.com 
tissue damage. The effects of pain can lead to a tremendous cost in health care costs, rehabilitation and lost worker productivity based on days of work missed, hours of work lost, and lower wages, as well as the emotional and financial burden it places on patients and their family. ${ }^{8}$

To relieve pain, the World Health Organization (WHO) provides a three steps management starting by giving non-opioids, mild-opioids and strong opioids. ${ }^{6}$ Paracetamol and some Non-steroidal Anti-inflammatory Drugs (NSAIDs) are categorized in nonopioids and available over-the-counter, and thus they are the most commonly used drugs for self-medication. ${ }^{9}$ Improper use of these drugs can lead to several side effects such as hepatic failure, gastrointestinal disturbance, cardiovascular problem and worsening of asthma. ${ }^{10,11}$

The WHO suggests that public health education and increased awareness are important. ${ }^{5}$ By determining the attitude and behaviour of the society, the current conditions on their drug usage can be assessed and the outcome might be used to plan an intervention to ensure good and safe self-medication among the community. As housewives are usually the ones who takes care of the household, this study was aimed to explore the attitude and behavior of Non-steroidal Anti-inflammatory Drugs (NSAIDs) and paracetamol among housewives in Jatinangor

\section{Methods}

This study was conducted in Hegarmanah Village, Jatinangor, West Java, Indonesia from August to November 2013. The study design was descriptive with a cross-sectional approach. The inclusion criteria were all married housewives who resided in the village and agreed to participate in this study by filling in an informed consent form. No exclusion criteria in this study. Permission from the local authorities was cleared and the study was approved by the Health Research Ethics Committee of Faculty of Medicine Universitas Padjadjaran (No: 241/UN6.C2.1.2/ KEPK/2013).

The questionnaire contained 9 questions related to attitude and 13 questions related to behavior. The attitude was explored by determining the responses on the application of the drugs on all levels of pain, correct dosage, the role of prescriptions in consuming the drugs, side effects, and usage of prescribed drugs. The responses on each statement were designated as 'agree' or 'not agree'. The behaviour was determined by assessing the habitual reasons for self-medications, types of pain-killer frequently used for pain, an indication of use, frequency and dosage intake of the drugs. The responses were stated as 'frequently', 'seldom' or 'never'. Furthermore, two questions had 'yes' or 'no' choices for answers.

Score was given and totaled up to classify the respondents into good ( $\geq 68 \%)$, moderate $(34-68 \%)$ and poor $(\leq 33 \%)$ for attitude; also good $(\geq 70 \%)$, moderate $(39-69 \%)$ and poor $(\leq 38 \%)$ for behavior. Four questions were not given scoring as these questions allowed the respondents to answer more than one answer, including questions about the type of analgesic used, the reason for self-doing medication use, the symptoms treated with self-medication, and the group of people for self -medication.

The questionnaire was first tested for validity and reliability before distributed to the respondents. For validity, each question was tested and correlated. A correlation value of $\geq 0.3$ was set to ensure that the question was valid. For reliability test, Cronbach's Alpha was tested by Statistical Product and Services Solutions (SPSS) statistics program. The questionnaire's coefficient reliability was considered reliable if $\geq 0.7$. The data was then collected and the results were presented in frequency and table forms.

Table 1 Education Level of Housewives in Hegarmanah Village, Jatinangor, Sumedang, West Java, Indonesia

\begin{tabular}{lcc}
\hline \multicolumn{1}{c}{ Education } & Frequency $(\mathbf{n = 1 0 0 )}$ & Percentage (\%) \\
\hline Elementary school & 60 & 54.6 \\
Junior High school & 31 & 28.2 \\
Senior High school & 18 & 16.4 \\
University Graduates & 1 & 0.9 \\
\hline
\end{tabular}



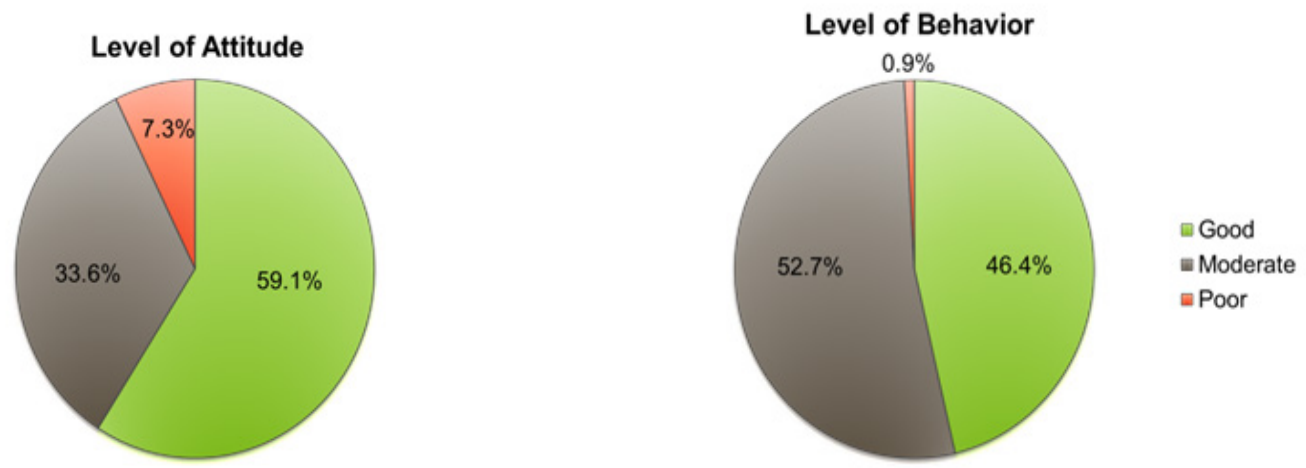

Figure 1 The Level of Attitude and Behaviour of Housewives in Hegarmanah Village Jatinangor, Sumedang, West Java, Indonesia during August-November 2013

\section{Results}

In total, there were 110 housewives recruited, with a mean age of 41 years old (s.d+12.5). The largest population of the study $(54.6 \%)$ was from the lowest education background which was elementary school, as depicted in Table 1.

Most of the respondents (59.1\%) had a good attitude towards the drug's usage, followed by moderate $(33.6 \%)$ and poor $(7.3 \%)$ attitude, whereas half of the respondents had moderate behavior $(52.7 \%)$, followed by good $(46.4 \%)$ and very little had a poor behavior $(0.9 \%)$ as shown in Figure 1. The type of analgesics used was paracetamol $(76.4 \%)$, which was the top on the list as the most chosen analgesic by the respondents (Figure 2).

The most chosen reason for doing selfmedication was 'no need to seek medical practitioner for minor ailments' (Table 2). The headache came as the most frequent reason (86.4\%) (Table 3), and most of the respondents use self-medication on themselves (99.1\%) (Table 4)

\section{Discussions}

This study has explored the attitude and behaviour of housewives aboutself-medication use. Overall, the attitudes on drugs use among housewives are good (59.1\%), however, their behaviour is moderate $(52.7 \%)$. Interestingly, most of respondents have elementary

\section{Type of Analgesics Used}

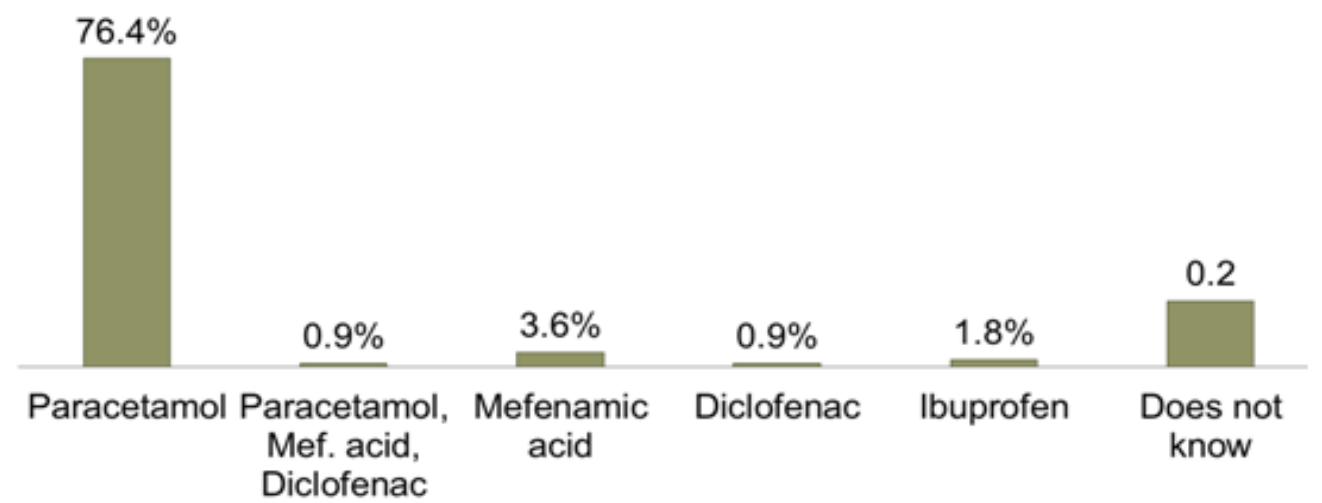

Figure 2 Types of Analgesic Used Housewives in Hegarmanah Village, Jatinangor, Sumedang, West Java, Indonesia 
Table 2 Reasons for Doing Self-medication

\begin{tabular}{lcc}
\hline \multicolumn{1}{c}{ Reasons } & $\begin{array}{c}\text { Frequency } \\
\text { (n=out of 110) }\end{array}$ & $\begin{array}{c}\text { Percentage } \\
\text { (\%) }\end{array}$ \\
\hline Time-saving & 29 & 26.4 \\
No need to seek medical practitioner for minor ailments & 42 & $38.2^{*}$ \\
Cheaper & 35 & 31.8 \\
Quick-relief & 36 & 32.7 \\
Analgesics drugs are easily available & 25 & 22.7 \\
Convenient & 34 & 30.9 \\
\hline
\end{tabular}

Note: * The most chosen reason

education (54.6\%). The percentages of respondents from each education background does not represent the proportion in the community itself, as only interested eligible participants have been taken as study subjects.

Most of the housewives have a good level of attitude on self-medication drugs. Generally, people are well aware of the side effects that may occur during self-medication. Most of them acknowledge that a doctor's role is necessary when the pain worsens or when they in need of controlled drugs. However, some still thought that it has no harm to buy controlled drugs themselves or even do self-dosing. A question has been asked to the respondents whether drug dosage could be reduced by them, and more than half of the respondents agreed on this, which is not a proper way to do.

Table 3 Symptoms Treated with Self-medication

\begin{tabular}{|c|c|c|}
\hline Symptoms & $\begin{array}{c}\text { Frequency } \\
(n=\text { out of 110) }\end{array}$ & $\begin{array}{c}\text { Percentage } \\
(\%)\end{array}$ \\
\hline Headache & 95 & 86.4 \\
\hline Toothache & 46 & 41.8 \\
\hline Fever & 42 & 38.2 \\
\hline Flu & 43 & 39.1 \\
\hline Joint pain & 26 & 23.6 \\
\hline Dysmenorrhea & 15 & 13.6 \\
\hline Diarrhea & 8 & 7.3 \\
\hline Breathing difficulty & 1 & 0.9 \\
\hline Nausea & 4 & 3.6 \\
\hline Others & 4 & 3.6 \\
\hline
\end{tabular}

Table 4 The Group of Individual for Self-medication

\begin{tabular}{lccc}
\hline Consumers & $\begin{array}{c}\text { Frequency } \\
\text { (n=out of 110) }\end{array}$ & $\begin{array}{c}\text { Percentage } \\
\text { (\%) }\end{array}$ \\
\hline Self & 109 & 99.1 \\
Husband & 36 & 32.7 \\
Children & 29 & 26.4 \\
Parents & 6 & 5.5 \\
Others & 3 & 2.7 \\
\hline
\end{tabular}


Interestingly, a study on medical students has shown that they increased the dose without medical advice. ${ }^{3}$ Incorrect drug dosage can lead to an improper practice of self-medication. ${ }^{12}$

As for the behaviour of the housewives in this study, most of them (52.7\%) had a moderate behaviour towards self-medication drugs and they do self-medication to counter pain. This is good as WHO acknowledges that self-medication is necessary to first encounter the pain. ${ }^{13}$ However, as stated in the attitude statement, even in the practice, most of the respondents will reduce drug dosage themselves. Some of the respondents did not, or only sometimes, follow the dosage requirement written on the drug's packaging, which is quite alarming. Apart from being harmful, wasting time and money, side effects can arise when the proper practice of selfmedication is ignored. ${ }^{12}$ This is one of the reasons that contribute to the moderate behaviour level of the respondents.

The most common drug used for selfmedication in this study is paracetamol as expected since paracetamol is one of the most drugs available easily on the market. ${ }^{9}$ Interestingly, some of the respondents have chosen mefenamic acid as their first choice of drug to counter pain. Mefenamic acid is not supposed to be sold OTC, as a prescription is needed to buy the drug. However, some pharmacies still sell controlled drugs even without prescription from the physician. Some respondents do not know the type of drugs that they took to alleviate pain, leading to problems in the future. By not knowing what kind of drugs they have taken, they may cause overdosage or usage of different classes of drugs that are inappropriate with the symptoms. ${ }^{12}$

Self-medication is time saving, no need to seek medical practitioners for minor ailments, cheaper, easily available, convenient and it gives quick relief. Comparing with a study among housewives in Northern India ${ }^{14}$, self-medication has been chosen because repeated consultations to the doctor may cause a burden to them financially and it is time-consuming. Physician is only consulted when the symptoms are serious enough or could not be relieved by medication. ${ }^{14}$ In our study, almost all respondents seek medical practitioners when symptoms worsen, which shows correct conduct of action as unrelieved pain may indicate a chronic medical condition, where medical intervention is needed. Correct conduct of self-medication can save patients' time from seeing doctors, it is economical and may even save a life in acute conditions. ${ }^{5}$
The most common symptoms treated by self-medication among the respondents are a headache. A study on self-medication among Iranian University Students has shown that the most common condition encountered with self-medication is headache, ${ }^{15}$ whereas in India common cold is the main reason for doing selfmedication. ${ }^{16}$ Dysmenorrhoea is also common for self-medication action since most of the respondents are in their reproductive age. Interestingly, some respondents have used analgesics for the wrong symptoms such as diarrhea, breathing difficulty and nausea. This improper act may lead to a complication, especially to those who have breathing difficulty and nausea since the consumption of NSAIDs can worsen asthma and may cause gastrointestinal disturbance. ${ }^{11}$ Almost all of the respondents have taken drugs for themselves, and most of them are reluctant to do selfmedication on their children because they are afraid of improper drug dosage given to their children. This shows that most of them have good awareness of the importance of proper drug usage.

There are several limitations to this study. Some respondents have been interviewed in small groups, therefore, some answers may not be truly answered leading to a possibility of measurement bias for some other respondents. However, it provides useful information on the attitude and behaviour of self-medication among housewives in Hegarmanah Village, Jatinangor. Further study is needed to elaborate and confirm these findings.

To conclude, the majority of the housewives in Hegarmanah village Jatinangor have moderate to good attitude as well as behavior toward the usage of NSAIDs and paracetamol as self-medication. An educational program on self-medication should be conducted to increase awareness to the society for them to practice safe and effective self-medication. The government must also be stricter on pharmacies as they should not sell controlled drugs to consumers without a prescription.

\section{References}

1. Aoyama I, Koyama S, Hibino H. Selfmedication behaviors among Japanese consumers: sex, age, and SES differences and caregivers' attitudes toward their children's health management. Asia Pac Fam Med. 2012;11(1):7.

2. Du Y, Knopf H. Self-medication among children and adolescents in Germany: results of the National Health Survey for 
Children and Adolescents (KiGGS). Br J Clin Pharmacol. 2009;68(4):599-608.

3. El Ezz NF, Ez-Elarab HS. Knowledge, attitude and practice of medical students towards self medication at Ain Shams University, Egypt. J Prev Med Hyg. 2011;52(4):196-200.

4. Badan Pusat Statistik Indonesia. Persentase penduduk yang mengobati sendiri selama sebulan terakhir menurut provinsi dan jenis obat yang digunakan, 2002-2018. Jakarta: BPS-Statistic Indonesia; 2019. [cited 2019 October 30] Available from: https://www.bps. go.id/dynamictable/2015/09/19/926/ persentase-penduduk-yang-mengobatisendiri-selama-sebulan-terakhirmenurut-provinsi-dan-jenis-obat-yangdigunakan-2002-2018.html

5. James H, Handu SS, Al Khaja KaJ, Otoom S, Sequeira RP. Evaluation of the knowledge, attitude and practice of self-medication among first-year medical students. Med Princ Pract. 2006;15(4):270-5.

6. World Health Organization. WHO's cancer pain ladder for adults; 2009. [cited 2019 October 30]. Available from: https://www. who.int/cancer/palliative/painladder/en/.

7. Chaerunissa AY, Surahman E, Imron SSH. Farmasetika dasar: konsep teoritis dan aplikasi pembuatan obat. Bandung, Indonesia: Widya Padjadjaran; 2009.

8. Institute of Medicine (US) Committee an Advancing Pain Research, Care, and Education. Relieving pain in America: A blueprint for transforming prevention, care, education, and research. Washington DC: National Academies Press; 2011.

9. Abay SM, Amelo W. Assessment of selfmedication practices among medical, pharmacy, and health science students in Gondar University, Ethiopia. J Young Pharm. 2010;2(3):306-10.

10. Bresalier RS, Sandler RS, Quan H, Bolognese JA, Oxenius B, Horgan $K$, et al. Cardiovascular events associated with rofecoxib in a colorectal adenoma chemoprevention trial. $\mathrm{N}$ Eng J Med. 2005;352(11):1092-102.

11. Süleyman H, Demircan B, Karagöz Y. Anti-inflammatory and side effects of cyclooxygenase inhibitors. Pharmacol Rep. 2007;59(3):247-58.

12. Supardi S, Notosiswoyo M. Pengobatan sendiri sakit kepala, demam, batuk dan pilek pada masyarakat di Desa Ciwalen, Kecamatan Warungkondang, Kabupaten Cianjur, Jawa Barat. Majalah Ilmu Kefarmasian. 2005;II(3):134-44

13. Suleman S, Ketsela A, Mekonnen Z. Assessment of self-medication practices in Assendabo town, Jimma zone, southwestern Ethiopia. Res Social Adm Pharm. 2009;5(1):76-81.

14. Kaushal J, Gupta M, Jindal P, Verma S. Selfmedication patterns and drug use behavior in housewives belonging to the middle income group in a city in Northern India. Indian J Community Med. 2012;37(1):16-9.

15. Sarahroodi S, Maleki-Jamshid A, Sawalha AF, Mikaili P, Safaeian L. Pattern of selfmedication with analgesics among Iranian University students in Central Iran. J Family Community Med. 2012;19(2):125-9.

16. Badiger S, Kundapur R, Jain A, Kumar A, Pattanshetty S, Thakolkaran N, et al. Self-medication patterns among medical students in South India. Australas Med J. 2012;5(4):217-20. 